\title{
PENGEMBANGAN SOAL HIGHER ORDER THINKING SKILLS (HOTS) PADA MATERI BARISAN DAN DERET BILANGAN
}

\author{
Nailul Farihah ${ }^{1 *}$, Ulil Nurul Imanah ${ }^{2}$, Eka Wahyu Hidayati ${ }^{3}$ \\ Universitas Islam Majapahit, Jl. Raya Jabon KM 0,7 Mojokerto \\ ${ }^{*}$ nailfarihah@gmail.com
}

\begin{abstract}
Abstrak
Penelitian pengembangan ini dilakukan dengan 2 tahap utama yaitu preliminary dan formative evaluation. Tahap formative evaluation meliputi self evaluation, expert review, one-to-one, small group dan field test. Untuk mengetahui kevalidan perangkat soal HOTS dilihat dari hasil analisis lembar validasi pada tahap expert review. Kepraktisan soal diketahui dari hasil analisis angket respon siswa pada tahap small group. Sedangkan efek potensial soal berdasarkan hasil analisis kemampuan berpikir tingkat tiggi siswa pada tahap field test. Hasil pengembangan soal HOTS ini berupa perangkat soal yang terdiri dari kisi-kisi dan soal HOTS dengan 5 soal berbentuk uraian yang memenuhi kriteria valid dan praktis. Perangkat soal dinyatakan valid dengan rata-rata kriteria skor sebesar $89 \%$ dalam kategori sangat valid, dan dinyatakan praktis dengan kriteria skor sebesar $83 \%$ dalam kategori sangat praktis. Soal HOTS yang dikembangkan juga memiliki efek potensial yang baik terhadap kemampuan berpikir tingkat tinggi siswa dengan skor rata-rata 15,6875 yang menunjukkan kemampuan berpikir tingkat tinggi siswa dalam kategori baik.
\end{abstract}

Kata kunci: Soal HOTS, Higher Order Thinking Skills, Barisan dan Deret

\begin{abstract}
This development research was conducted in two main stages: preliminary and formative evaluation. Formative evaluation includes self evaluation, expert review, one-to-one, small group and field test. Validity of HOTS questions is known from the results of the validation analysis at the expert review. The question's practicality is known from the results of the student response questionnaire in the small group. The question's potential effects are based on the analysis of the students' thinking skills level in the field test stage. The results of this development are grids and 5 HOTS questions with valid and practical criteria. The questions is valid with an average score $89 \%$ (very valid), and practical with a score $83 \%$ (very practical). The HOTS question developed also has a good potential effect on students' high-level thinking skills with an average score of 15.6875 which shows students' high-level thinking skills in good categories.
\end{abstract}

Kata kunci: HOTS question, Higher Order Thinking Skills, number sequence and series 


\section{Pendahuluan}

Hasil capaian PISA (Programme for International Student Assessment) tahun 2015 menunjukkan bahwa Indonesia menempati posisi kedua dari bawah. Indonesia masih jauh berada di bawah rata-rata nilai negara OECD (Organisation for Economic Cooperation and Development) terutama pada kompetensi matematika. Capaian nilai matematika negara Indonesia pada PISA 2015 paling rendah dibandingkan dua kompetensi lainnya yaitu sains dan membaca (OECD, 2016: 4).

Hasil riset internasional tiga tahunan terakhir, yakni PISA 2015, menunjukkan masih rendahnya mutu pendidikan di Indonesia. Salah satu faktor penyebabnya ialah peserta didik di Indonesia kurang terlatih dalam menyelesaikan soal-soal kontekstual yang melibatkan penalaran, kreativitas seperti soal yang diujikan dalam PISA (Budiman \& Jailani, 2014: 140). Hal ini sejalan dengan pernyataan Kemdikbud (2014: 2) bahwa rendahnya capaian anak Indonesia dalam PISA disebabkan banyak materi uji yang ditanyakan di PISA namun tidak terdapat dalam kurikulum Indonesia.

Bersamaan dengan dikeluarkannya kurikulum terbaru, Permendikbud nomor 23 tahun 2016 tentang Standar Penilaian Pendidikan mengamanatkan bahwa pemanfaatan, mekanisme, dan prosedur penilaian oleh pendidik diatur dalam pedoman yang disusun oleh Direktorat Jenderal terkait berkoordinasi dengan Badan Penelitian dan Pengembangan Kementerian Pendidikan dan Kebudayaan. Kemudian dalam naskah Panduan penilaian oleh Pendidik dan Satuan Pendidikan SMA (Dirjendikdasmen, 2017: 28) dinyatakan bahwa Penilaian untuk SMA sebaiknya lebih banyak menilai keterampilan berpikir tingkat tinggi/ high order thinking skills (HOTS) yaitu bentuk soal yang memiliki tingkatan berpikir menganalisis, mengevaluasi, sampai ke mencipta.

Permasalahan yang terjadi di sekolah, kurikulum 2013 telah diterapkan namun soal-soal cenderung lebih banyak menguji aspek ingatan yang kurang melatih keterampilan berpikir tingkat tinggi siswa. Hal ini juga didukung oleh pernyataan salah satu guru Matematika di SMAN 1 Puri bahwa soal HOTS termasuk hal yang baru dicanangkan di kurikulum 2013 terbaru, jadi masih belum banyak digunakan dalam pelajaran Matematika. Hal ini dikarenakan kemampuan guru dalam mengembangkan soal yang menguji keterampilan berpikir tingkat tinggi (HOTS) masih kurang.

Dimensi proses kognitif dalam Taksonomi Bloom sebagaimana yang telah disempurnakan oleh Anderson \& Krathwolh (Krathwolh, 2002: 215) terdiri atas 
kemampuan: mengingat (remember-C1), memahami (understand-C2), menerapkan (apply-C3), menganalisis (analyze-C4), mengevaluasi (evaluate-C5), dan mencipta/ mengkreasi (create-C6). Kemampuan tersebut secara runtut merupakan kemampuan berpikir dari tingkat rendah sampai tinggi. Dimensi proses kognitif yang termasuk dalam kategori kemampuan berpikir tingkat tinggi/ higher order thinking skills adalah kemampuan menganalisis, mengevaluasi dan mencipta/ mengkreasi.

Salah satu materi dalam mata pelajaran matematika yaitu barisan dan deret bilangan. Dalam Matematika Kelas XI SMA/MA/SMK/MAK (Kemdikbud, 2017: 182) proses pembelajaran barisan, berbagai konsep dan aturan matematika terkait barisan akan ditemukan melalui pemecahan masalah, melihat pola susunan bilangan, dan menemukan berbagai strategi sebagai alternatif pemecahan masalah. Menemukan berbagai strategi dalam pemecahan masalah merupakan kemampuan yang akan dihasilkan dalam pengembangan kemampuan berpikir tingkat tinggi menurut Budiman dan Jailani (2014: 142), dan melihat pola susunan dalam barisan dan deret bilangan juga memerlukan Higher Order Thinking Skills yang dalam hal ini termasuk dalam ranah kemampuan analisis.

Berdasarkan latar belakang di atas, pertanyaan penelitian yang diajukan dalam penelitian ini yaitu: 1) Bagaimana proses dan hasil pengembangan soal Higher Order Thinking Skills (HOTS) pada materi barisan dan deret bilangan yang valid dan praktis di SMA Negeri 1 Puri?, 2) Bagaimana efek potensial soal Higher Order Thinking Skills (HOTS) terhadap kemampuan berpikir tingkat tinggi siswa pada materi barisan dan deret bilangan di SMA Negeri 1 Puri?

Tujuan yang akan dicapai dalam penelitian ini yaitu: 1) Menjelaskan proses dan hasil pengembangan soal Higher Order Thinking Skills (HOTS) pada materi barisan dan deret bilangan yang valid dan praktis di SMA Negeri 1 Puri, dan 2) Melihat efek potensial soal Higher Order Thinking Skills (HOTS) terhadap kemampuan berpikir tingkat tinggi siswa pada materi barisan dan deret bilangan di SMA Negeri 1 Puri.

\section{Metode Penelitian}

Jenis penelitian yang akan dilakukan dalam penelitian ini adalah penelitian dan pengembangan, atau bisa disebut dengan R\&D (Research and Development). Sekolah yang dipilih oleh peneliti untuk melakukan penelitian dan pengembangan ini adalah SMA Negeri 1 Puri. Subjek penelitiannya merupakan siswa kelas XI MIPA SMA Negeri 1 Puri 
tahun akademik 2017/2018 dengan kemampuan matematika tinggi berdasarkan nilai pengetahuan matematika dan saran dari guru mata pelajaran matematika di sekolah tersebut.

Prosedur penelitian dalam penelitian dan pengembangan ini terbagi menjadi dua tahap utama yakni tahap preliminary dan formative evaluation. Tahap formative evaluation menurut Tessmer (1998: 16) meliputi self evaluation, expert review, one-toone, small group dan field test.

1. Tahap preliminary, merupakan tahap persiapan atau pendahuluan. Pada tahap ini peneliti menentukan lokasi penelitian yakni SMA Negeri 1 Puri. Peneliti menghubungi kepala sekolah dan guru mata pelajaran matematika di sekolah yang akan dijadikan tempat penelitian tersebut. Peneliti juga melakukan persiapan lainnya seperti menjalin kerja sama dan mengatur jadwal penelitian dengan guru kelas.

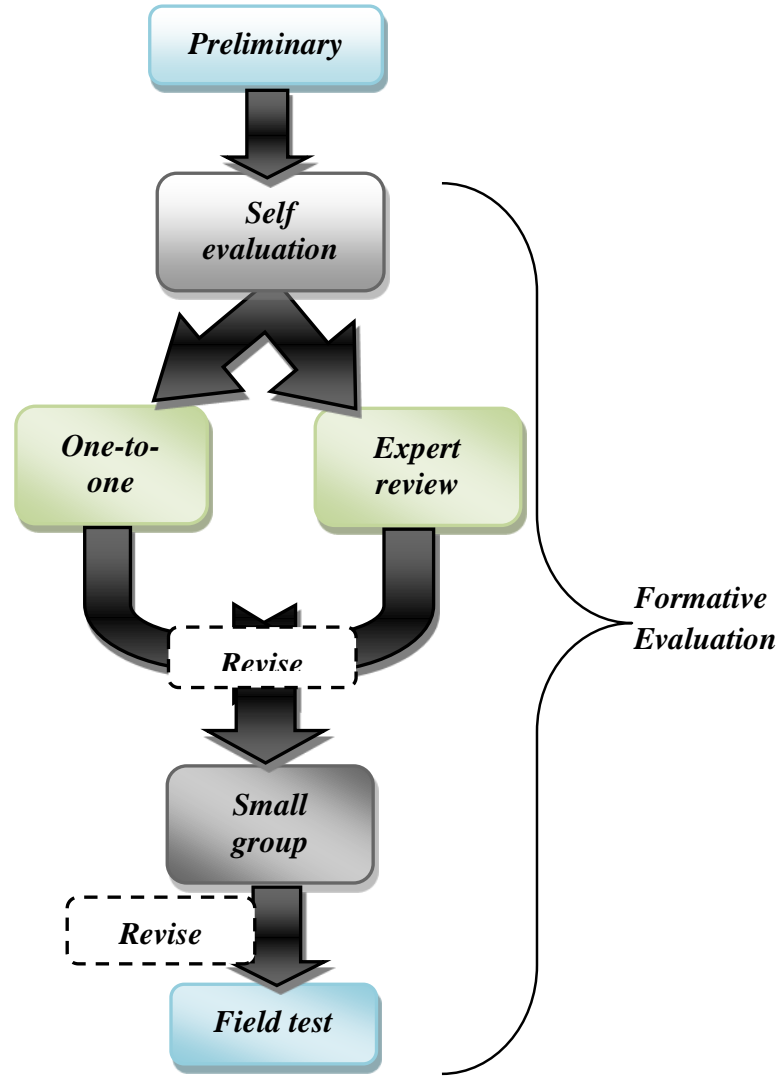

Gambar 1. Alur Desain Formative Evaluation (Tessmer dalam Zulkardi, 2006)

2. Tahap Formative Evaluation 
a. Self evaluation. Pada tahap ini peneliti melakukan analisis literatur mengenai soal HOTS serta analisis materi Barisan dan Deret yang sesuai dengan kurikulum 2013. Peneliti mendesain perangkat soal HOTS pada materi Barisan dan Deret Bilangan berdasarkan karakteristik soal HOTS dan disesuaikan dengan materi barisan dan deret bilangan untuk kelas XI MIPA.

b. Expert review. Prototype soal yang dihasilkan dari tahap self evaluation selanjutnya diberikan kepada pakar. Pakar-pakar tadi akan menelaah substansi, konstruksi dan bahasa dari masing-masing prototype. Tahap expert review (uji coba pakar) dapat disebut dengan uji validitas. Tanggapan dan saran dari para validator atau pakar tentang desain yang telah dibuat, saran-saran validator ditulis pada lembar validasi sebagai bahan merevisi dan menyatakan bahwa soalsoal untuk mengukur kemampuan berpikir tingkat tinggi tersebut telah valid.

c. One to one. Pada tahap ini peneliti meminta salah seorang siswa untuk mengerjakan prototype awal yang telah dibuat, kemudian mengamati bagaimana siswa tersebut mengerjakan dan meminta komentar atau pendapat siswa terhadap soal yang telah dikerjakan. Hasil komentar atau saran dari siswa mengenai kejelasan prototype tersebut akan dijadikan bahan masukan untuk merevisi perangkat soal Higher Order Thinking Skills (HOTS) yang sedang dikembangkan.

d. Small group. Pada tahap ini peneliti meminta 5 orang siswa untuk menyelesaikan prototype soal yang telah dibuat. Siswa yang digunakan sebagai tester pada small group merupakan siswa yang memiliki kriteria tidak jauh berbeda dari subjek penelitian yaitu siswa kelas XI MIPA dengan kemampuan matematika tinggi. Berdasarkan hasil tes uji coba dan komentar siswa inilah produk direvisi dan diperbaiki lagi.

e. Field test. Tahap dimana perangkat soal yang telah direvisi pada tahap sebelumnya diujicobakan ke sekelompok siswa yang merupakan subjek penelitian, yaitu 16 siswa kelas XI MIPA SMA Negeri 1 Puri tahun akademik 2017/2018 dengan kemampuan matematika tinggi. Pada tahap ini, akan didapatkan hasil tes kemampuan berpikir tingkat tinggi (higher order thinking skills) siswa dari perangkat soal yang dikembangkan yang dinilai berdasarkan indikator kemampuan berpikir tingkat tinggi dan kemudian dikategorikan 
berdasarkan kategori kemampuan berpikir tingkat tinggi. Hasil tes ini yang akan digunakan untuk melihat efek potensial dari soal yang dikembangkan.

Teknik pengumpulan data yang digunakan dalam penelitian yaitu kuesioner (angket), tes dan wawancara. Kuesioner (angket) digunakan pada tahap small group untuk mengetahui respon siswa terhadap prototype soal dan pada tahap expert review untuk menilai kevalidan perangkat soal. Tes digunakan pada tahap field test untuk mengetahui efek potensial soal HOTS terhadap kemampuan berpikir tingkat tinggi siswa. Wawancara dalam penelitian bersifat tidak terstruktur untuk mengetahui kesulitan yang mungkin ditemui oleh subjek one to one dalam mengerjakan prototipe soal HOTS

Analisis data perolehan dari teknik pengumpulan data diantaranya yaitu analisis kevalidan dan kepraktisan perangkat soal, serta efek potensial soal HOTS. Kevalidan pada penelitian ini dilihat dari hasil angket validasi yang diisi oleh para pakar untuk menilai perangkat soal yang dikembangkan, kemudian dianalisis berdasarkan tingkat kevalidan. Sedangkan kepraktisan dilihat dari hasil angket respon siswa mengenai soal HOTS, kemudian dianalisis berdasarkan tingkat kepraktisan.

Tabel 1. Tingkat Kevalidan Perangkat Soal HOTS

\begin{tabular}{ccc}
\hline No & Kriteria Skor & Tingkat Validasi \\
$\mathbf{1}$ & $75,01 \%-100 \%$ & Sangat valid \\
$\mathbf{2}$ & $50,01 \%-75 \%$ & Valid \\
$\mathbf{3}$ & $25,01 \%-50 \%$ & Kurang valid \\
$\mathbf{4}$ & $0 \%-25 \%$ & Tidak valid \\
\hline
\end{tabular}

Tabel 2. Tingkat Kepraktisan Perangkat Soal HOTS

\begin{tabular}{ccc}
\hline No & Kriteria Skor & Tingkat Kepraktisan \\
$\mathbf{1}$ & $75,01 \%-100 \%$ & Sangat praktis \\
$\mathbf{2}$ & $50,01 \%-75 \%$ & Praktis \\
$\mathbf{3}$ & $25,01 \%-50 \%$ & Kurang praktis \\
$\mathbf{4}$ & $0 \%-25 \%$ & Tidak praktis \\
\hline
\end{tabular}

Hasil tes siswa dalam mengerjakan soal HOTS pada field test dianalisis berdasarkan sistem penskoran yang mengacu pada indikator kemampuan berpikir tingkat tinggi (higher order thinking skills) menurut Krathwohl (dalam Lewy, Zulkardi, \& Aisyah, 2009: 16). Indikator yang dimaksud meliputi 3 deskriptor dari setiap kemampuan yang dapat dijelaskan sebagai berikut:

1) Menganalisis 
- Menganalisis informasi yang masuk dan membagi-bagi atau menstrukturkan informasi ke dalam bagian yang lebih kecil untuk mengenali pola atau hubungannya

- Mampu mengenali serta membedakan faktor penyebab dan akibat dari sebuah skenario yang rumit

- Mengidentifikasi/ merumuskan pertanyaan

2) Mengevaluasi

- Memberikan penilaian terhadap solusi, gagasan, dan metodologi dengan menggunakan kriteria yang cocok atau standar yang ada untuk memastikan nilai efektivitas atau manfaatnya

- Membuat hipotesis, mengkritik dan melakukan pengujian

- Menerima atau menolak suatu pernyataan berdasarkan kriteria yang telah ditetapkan

3) Mengkreasi

- Membuat generalisasi suatu ide atau cara pandang terhadap sesuatu

- Merancang suatu cara untuk menyelesaikan masalah

- Mengorganisasikan unsur-unsur atau bagian-bagian menjadi struktur baru yang belum pernah ada sebelumnya

Penskoran kemampuan berpikir tingkat tinggi siswa dalam mengerjakan soal HOTS didasarkan pada kenampakan deskriptornya. Kemudian skor tersebut dikonversikan ke dalam data kualitatif berdasarkan kategori kemampuan berpikir tingkat tinggi siswa.

Tabel 3. Sistem Penskoran Kemampuan Berpikir Tingkat Tinggi Siswa

\begin{tabular}{cc}
\hline Skor & Kriteria \\
$\mathbf{4}$ & Tampak 3 deskriptor \\
$\mathbf{3}$ & Tampak 2 deskriptor \\
$\mathbf{2}$ & Tampak 1 deskriptor \\
$\mathbf{1}$ & Tampak 0 deskriptor \\
\hline
\end{tabular}

Tabel 4. Kategori Kemampuan Berpikir Tingkat Tinggi Siswa

\begin{tabular}{cc}
\hline Skor Total & Kategori Kemampuan Berpikir Tingkat Tinggi \\
$\mathbf{1 7}-\mathbf{2 0}$ & Sangat Baik \\
$\mathbf{1 3}-\mathbf{1 6}$ & Baik \\
$\mathbf{9}-\mathbf{1 2}$ & Cukup \\
$\mathbf{5 - 8}$ & Kurang \\
\hline
\end{tabular}

Dalam penelitian ini soal dikatakan memiliki efek potensial jika rata-rata skor keseluruhan siswa menunjukkan kemampuan berpikir tingkat tinggi pada kategori baik atau sangat baik.

\section{Hasil dan Pembahasan}


Pengembangan soal HOTS pada materi barisan dan deret bilangan telah melalui serangkaian prosedur penelitian mulai tahap preliminary hingga tahap formative evaluation menurut Tessmer (1998: 16) yang meliputi self evaluation, expert review, oneto-one, small group dan field test.

Pada tahap preliminary peneliti melakukan persiapan penelitian dengan mendatangi lokasi penelitian yakni SMA Negeri 1 Puri. Peneliti bersama guru matematika sekolah tersebut mendiskusikan jadwal penelitian yang akan dilakukan.. Waktu penelitian dengan rentang tanggal 7 sampai 28 Mei 2018.

Tahap self evaluation meliputi kegiatan analisis literatur, analisis materi dan desain. Analisis literatur dilakukan dengan mengkaji beberapa referensi mengenai pengembangan soal HOTS sehingga didapatkan 2 karakteristik soal HOTS yang digunakan dalam penelitian ini yaitu mengukur kemampuan berpikir tingkat tinggi dan berbasis permasalahan kontekstual. Analisis materi dilakukan dengan mengkaji materi barisan dan deret bilangan yang ada pada buku Matematika Kelas XI (Aksin, Astinto, \& Miyanto, 2017) yang sesuai dengan kurikulum 2013 terbaru dan digunakan dalam pembelajaran di SMAN 1 Puri. Sedangkan desain perangkat soal HOTS disesuaikan dengan hasil analisis literatur dan materi yang telah dilakukan, sehingga didapatkan 5 soal HOTS materi barisan dan deret bilangan berbentuk uraian sebagai prototipe awal.

Prototipe awal yang telah didesain peneliti diberikan kepada 3 validator pada tahap expert review untuk mendapatkan penilaian serta masukan atau saran. Saran yang diberikan diantaranya mengenai penulisan kata, judul gambar dan tanda baca, penyelesaian soal yang kurang menggunakan konsep barisan dan deret, serta penggunaan angka agar sesuai konteks. Penilaian dari ketiga validator dianalisis berdasarkan teknik analisis data kevalidan soal dan tersaji dalam tabel 5.

Tabel 5. Hasil Validasi Soal HOTS pada Materi Barisan dan Deret Bilangan

\begin{tabular}{|c|c|c|c|c|c|c|c|}
\hline \multirow{2}{*}{ No. } & \multirow{2}{*}{ Aspek } & \multirow{2}{*}{$\begin{array}{c}\text { No. } \\
\text { Pernya- } \\
\text { taan }\end{array}$} & \multicolumn{3}{|c|}{ Skor Penilaian Validator } & \multirow{2}{*}{$\begin{array}{c}\text { Jumlah Skor } \\
\text { Setiap Kategori }\end{array}$} & \multirow{2}{*}{$\begin{array}{l}\text { Jumlah Skor } \\
\text { Setiap Aspek }\end{array}$} \\
\hline & & & 1 & 2 & 3 & & \\
\hline \multirow{5}{*}{1} & \multirow{5}{*}{$\begin{array}{l}\text { Substansi/ } \\
\text { Materi }\end{array}$} & 1 & 3 & 4 & 4 & 11 & \multirow{5}{*}{55} \\
\hline & & 2 & 4 & 4 & 4 & 12 & \\
\hline & & 3 & 3 & 3 & 4 & 10 & \\
\hline & & 4 & 3 & 3 & 4 & 10 & \\
\hline & & 5 & 4 & 4 & 4 & 12 & \\
\hline \multirow{3}{*}{2} & \multirow{3}{*}{ Konstruksi } & 6 & 4 & 4 & 4 & 12 & \multirow{3}{*}{75} \\
\hline & & 7 & 3 & 3 & 4 & 10 & \\
\hline & & 8 & 3 & 4 & 4 & 11 & \\
\hline
\end{tabular}




\begin{tabular}{|c|c|c|c|c|c|c|c|}
\hline & & 9 & 3 & 4 & 3 & 10 & \\
\hline & & 10 & 3 & 3 & 4 & 10 & \\
\hline & & 11 & 3 & 3 & 4 & 10 & \\
\hline & & 12 & 4 & 4 & 4 & 12 & \\
\hline \multirow{3}{*}{3} & \multirow{3}{*}{ Bahasa } & 13 & 3 & 4 & 4 & 11 & \multirow{3}{*}{31} \\
\hline & & 14 & 3 & 3 & 4 & 10 & \\
\hline & & 15 & 3 & 3 & 4 & 10 & \\
\hline \multicolumn{3}{|c|}{ Total Skor } & 49 & 53 & 59 & \multicolumn{2}{|c|}{161} \\
\hline \multicolumn{3}{|c|}{ Kriteria Skor } & $82 \%$ & $88 \%$ & $98 \%$ & & \\
\hline \multicolumn{3}{|c|}{$\begin{array}{c}\text { Rata-rata Kevalidan } \\
\text { Soal HOTS }\end{array}$} & \multicolumn{3}{|c|}{$89 \%$} & \multicolumn{2}{|c|}{ Sangat Valid } \\
\hline
\end{tabular}

Berdasarkan tabel 5 diketahui bahwa rata-rata kevalidan soal memiliki kriteria skor 89\%. Menurut klasifikasi tingkat validasi oleh Amin (2016: 96) soal HOTS yang dikembangkan berada pada kategori sangat valid, sehingga soal dinyatakan valid dan dapat digunakan pada tahap selanjutnya dengan melakukan revisi dari saran perbaikan yang diberikan oleh validator

Perangkat soal yang telah direvisi dari tahap expert review dan dinyatakan valid kemudian diujicobakan kepada salah seorang siswa XI MIPA 3 yang menjadi subjek one to one. Siswa tersebut mengerjakan soal HOTS dan mengalami kesulitan pada soal nomor 2. Kesulitan tersebut yang dijadikan bahan masukan bagi peneliti untuk merevisi soal lebih lanjut dengan memperbaiki kalimat soal nomor 2.

Pada tahap small group perangkat soal yang telah direvisi dari tahap sebelumnya diujikan kepada 5 siswa XI MIPA 3. Siswa sebagai subjek small group tersebut mengerjakan soal HOTS kemudian mengisi angket respon mengenai soal HOTS untuk menilai kepraktisan perangkat soal dan memberi masukan atau saran. Masukan yang diberikan diantaranya mengenai penggunaan kata dalam sebuah kalimat, sehingga dilakukan perbaikan kalimat yang ada pada soal nomor 5. Untuk hasil analisis angket respon siswa terhadap soal HOTS tersaji pada tabel 6.

Tabel 6 Hasil Analisis Angket Respon Siswa Terhadap Soal HOTS

\begin{tabular}{|c|c|c|c|c|c|c|}
\hline \multirow{2}{*}{$\begin{array}{c}\text { Nomor } \\
\text { Pernyataan }\end{array}$} & \multicolumn{5}{|c|}{ Skor Penilaian Siswa } & \multirow{2}{*}{ Jumlah Skor } \\
\cline { 2 - 6 } & $\mathbf{1}$ & $\mathbf{2}$ & $\mathbf{3}$ & $\mathbf{4}$ & $\mathbf{5}$ & \\
\hline 1 & 3 & 2 & 3 & 3 & 3 & 14 \\
\hline 2 & 4 & 3 & 4 & 4 & 3 & 18 \\
\hline 3 & 3 & 3 & 3 & 4 & 4 & 17 \\
\hline 4 & 2 & 4 & 3 & 2 & 4 & 15 \\
\hline 5 & 4 & 3 & 3 & 4 & 3 & 17 \\
\hline
\end{tabular}




\begin{tabular}{|c|c|c|c|c|c|c|}
\hline 6 & 4 & 2 & 3 & 3 & 3 & 12 \\
\hline 7 & 3 & 3 & 4 & 3 & 4 & 17 \\
\hline 8 & 3 & 3 & 3 & 4 & 2 & 15 \\
\hline 9 & 3 & 4 & 4 & 3 & 4 & 18 \\
\hline 10 & 3 & 4 & 4 & 3 & 4 & 18 \\
\hline 11 & 3 & 4 & 3 & 3 & 4 & 17 \\
\hline 12 & 3 & 4 & 3 & 3 & 4 & 17 \\
\hline \multicolumn{6}{|c|}{ Total Skor } & 198 \\
\hline \multicolumn{6}{|c|}{ Kriteria Skor } & $83 \%$ \\
\hline \multicolumn{4}{|c|}{ Tingkat Kepraktisan Soal HOTS } & \multicolumn{2}{|c|}{$83 \%$} & Sangat Praktis \\
\hline
\end{tabular}

Berdasarkan hasil analisis angket respon siswa, didapatkan bahwa kriteria skor kepraktisan soal HOTS yaitu 83\%. Menurut klasifikasi tingkat kepraktisan yang diadaptasi dari Amin (2016: 96) soal HOTS yang dikembangkan peneliti berada pada kategori sangat praktis. Karena soal berada pada ketegori sangat praktis, maka soal HOTS memenuhi kriteria praktis.

Soal yang telah direvisi dan dinyatakan praktis diujicobakan pada tahap terakhir yaitu field test. Tahap ini dilaksanakan Senin, 28 Mei 2018 dengan subjek 16 siswa berkemampuan tinggi dari kelas XI MIPA 1, 2, 3 dan 4 SMAN 1 Puri yang terdiri atas 4 siswa laki-laki dan 12 siswa perempuan. Subjek tersebut mengerjakan soal HOTS yang dikembangkan peneliti dalam waktu 90 menit. Hasil tes siswa digunakan untuk mengetahui kemampuan berpikir tingkat tinggi, kemudian digunakan untuk meilhat efek potensial dari soal HOTS yang dikembangkan. Berikut analisis data hasil tes soal HOTS siswa pada tahap field test:

Tabel 7. Daftar Skor Kemampuan Berpikir Tingkat Tinggi Siswa XI MIPA SMA Negeri 1 Puri

\begin{tabular}{|c|l|c|c|c|c|c|c|}
\hline \multirow{2}{*}{ No. } & \multirow{2}{*}{ Nama Siswa } & \multicolumn{7}{|c|}{ Skor Soal } & \multirow{2}{*}{ Total Skor } \\
\cline { 3 - 7 } & & $\mathbf{1}$ & $\mathbf{2}$ & $\mathbf{3}$ & $\mathbf{4}$ & $\mathbf{5}$ & \\
\hline 1 & A D U & 4 & 2 & 4 & 2 & 4 & 16 \\
\hline 2 & A N N A & 4 & 3 & 3 & 2 & 3 & 15 \\
\hline 3 & A N N & 2 & 4 & 2 & 1 & 4 & 13 \\
\hline 4 & B A & 1 & 2 & 3 & 3 & 3 & 12 \\
\hline 5 & B P M & 4 & 2 & 4 & 2 & 4 & 16 \\
\hline 6 & C M A & 4 & 1 & 3 & 4 & 2 & 14 \\
\hline 7 & D S B & 4 & 3 & 4 & 4 & 4 & 19 \\
\hline 8 & E A S & 4 & 1 & 3 & 4 & 2 & 14 \\
\hline 9 & F A & 4 & 2 & 3 & 2 & 4 & 15 \\
\hline 10 & F F & 4 & 3 & 3 & 2 & 4 & 16 \\
\hline 11 & M F A & 4 & 3 & 4 & 4 & 4 & 19 \\
\hline
\end{tabular}




\begin{tabular}{|c|l|c|c|c|c|c|c|}
12 & N A N & 4 & 2 & 3 & 4 & 2 & 15 \\
\hline 13 & P S & 4 & 3 & 4 & 4 & 3 & 18 \\
\hline 14 & S C P & 4 & 3 & 4 & 2 & 4 & 17 \\
\hline 15 & V V R & 4 & 2 & 3 & 4 & 2 & 15 \\
\hline 16 & W A L & 4 & 2 & 4 & 4 & 3 & 17 \\
\hline \multicolumn{2}{r|}{ Rata-rata } & 3,6875 & 2,375 & 3,375 & 3 & 3,25 & $\mathbf{1 5 , 6 8 7 5}$ \\
\hline
\end{tabular}

Tabel 8. Distribusi Skor Kemampuan Berpikir Tingkat Tinggi Siswa XI MIPA SMA Negeri 1 Puri

\begin{tabular}{cccc}
\hline Interval Skor & Frekuensi & Persentase & $\begin{array}{c}\text { Kategori Kemampuan } \\
\text { Berpikir Tingkat Tinggi }\end{array}$ \\
$\mathbf{1 7 - \mathbf { 2 0 }}$ & 5 & $31 \%$ & Sangat Baik \\
$\mathbf{1 3}-\mathbf{1 6}$ & 10 & $63 \%$ & Baik \\
$\mathbf{9 - \mathbf { 1 2 }}$ & 1 & $6 \%$ & Cukup \\
$\mathbf{5 - 8}$ & 0 & $0 \%$ & Kurang \\
\hline Jumlah & 16 & $100 \%$ & Baik \\
\hline Skor rata-rata & $\mathbf{1 5 , 6 8 7 5}$ & \\
\hline
\end{tabular}

Berdasarkan hasil analisis data tes tersebut didapatkan skor rata-rata siswa sebesar 15,6875 dimana kemampuan bepikir tingkat tinggi siswa berada kategori baik. Dengan demikian soal HOTS yang dikembangkan oleh peneliti memiliki efek potensial yang baik terhadap kemampuan berpikir tingkat tinggi siswa. Hal ini sejalan dengan penelitian Lewy, Zulkardi \& Aisyah (2009: 27) yang mengembangkan soal untuk mengukur kemampuan berpikir tingkat tinggi siswa kelas IX dan memiliki efek potensial soal yang baik.

\section{Simpulan dan Saran}

Berdasarkan hasil penelitian dan pembahasan penelitian ini memiliki simpulan sebagai berikut:

1. Proses pengembangan soal HOTS pada materi barisan dan deret bilangan dilakukan melalui dua tahap utama. Tahap pertama yaitu preliminary yang merupakan tahap persiapan, dimana peneliti mendatangi sekolah SMAN 1 Puri sekaligus meminta izin untuk melakukan penelitian dan merencanakan jadwal penelitian bersama guru matematika sekolah tersebut. Kemudian tahap kedua yaitu formative evaluation yang meliputi self evaluation, one to one, small group dan field test. Pada tahap self evaluation peneliti melakukan analisis literatur serta materi dan mendesain perangkat soal HOTS. Soal yang didesain selanjutnya divalidasi dan diberi saran oleh 3 validator pada tahap expert review. Soal yang telah direvisi berdasarkan saran validator dan dinyatakan valid diujicobakan kepada salah satu siswa pada tahap one to one. Soal diperbaiki dengan sedikit revisi berdasarkan kesulitan yang dihadapi 
subjek one to one kemudian diujikan kepada 5 siswa pada tahap small group. Pada tahap tersebut soal dinilai kepraktisannya berdasarkan angket respon siswa dan mendapatkan revisi lagi dari komentar atau saran subjek small group. Soal yang telah direvisi dan dinyatakan praktis diujicobakan pada tahap terakhir yaitu field test untuk mengetahui efek potensial soal yang dikembangkan. Hasil pengembangan soal HOTS ini berupa perangkat soal yang terdiri dari kisi-kisi dan soal HOTS dengan 5 soal berbentuk uraian yang memenuhi kriteria valid dan praktis. Perangkat soal dinyatakan valid berdasarkan hasil penilaian validator dengan rata-rata kriteria skor sebesar $89 \%$ yang menunjukkan kategori sangat valid. Perangkat soal juga dinyatakan praktis berdasarkan analisis angket respon siswa dengan kriteria skor sebesar $83 \%$ yang berada dalam kategori sangat praktis.

2. Soal HOTS yang dikembangkan memiliki efek potensial yang baik terhadap kemampuan berpikir tingkat tinggi siswa pada materi barisan dan deret bilangan di SMA Negeri 1 Puri. Hal ini tergambar dari hasil analisis pengerjaan soal HOTS siswa pada tahap field test dengan skor rata-rata 15,6875 yang menunjukkan kemampuan berpikir tingkat tinggi siswa dalam kategori baik.

Sedangkan saran yang diberikan untuk penelitian lebih lanjut sebagai berikut:

1. Sebaiknya soal HOTS yang dikembangkan tidak hanya untuk memenuhi kriteria valid dan praktis, melainkan bisa ditambahkan untuk kriteria soal lainnya seperti reliabel dan tingkat kesukaran soal, agar soal yang dihasilkan mempunyai kualitas yang lebih baik

2. Sebaiknya soal HOTS yang dikembangkan bisa memenuhi ketiga karakteristik soal HOTS yaitu mengukur kemampuan berpikir tingkat tinggi, berbasis permasalahan kontekstual dan menggunakan bentuk soal beragam. Dengan demikian, soal HOTS yang dikembangkan tidak hanya berbentuk uraian saja sehingga menjadi lebih variatif.

3. Sebaiknya jumlah subjek dari setiap tahap bisa lebih banyak, terutama pada tahap terakhir yaitu field test. Dengan subjek yang lebih banyak maka hasil penelitian yang didapatkan lebih objektif.

\section{Referensi}

Aksin, N., Astinto, A. Y., \& Miyanto. (2017). PR Matematika Kelas XI Semester 1. Klaten: Intan Pariwara. 
Amin, D. D. (2016). Pengembangan Bahan Ajar Matematika Materi Keliling dan Luas Lingkaran dengan Pendekatan Discovery Learning untuk SMP Kelas VIII. Skripsi

Budiman, A., \& Jailani. (2014). Pengembangan Instrumen Asesmen Higher Order Thinking Skills (HOTS) pada Mata Pelajaran Matematika SMP Kelas VIII Semester 1. Jurnal Riset Pendidikan Matemtika , 1 (2), 139-151.

Dirjendikdasmen. (2017). Modul Penyusunan Soal Higher Order Thinking Skills (HOTS). Jakarta: Kementerian Pendidikan dan Kebudayaan.

Dirjendikdasmen. (2017). Panduan Penilaian oleh Pendidik dan Satuan Pendidikan Sekolah Menengah Atas. Jakarta: Kemdikbud

Dirjendikdasmen. (2015). Panduan Penyusunan Soal Standar Internasional. Jakarta: Kemdikbud.

Kemdikbud. (2017). Matematika Kelas XI SMA/MA/SMK/MAK. Jakarta: Kementerian Pendidikan dan kebudayaan.

Kemdikbud. (2016). Peraturan Menteri Pendidikan dan Kebudayaan RI Nomor 23 tahun 2016 tentang Standar Nasional Pendidikan.

Kemdikbud. (2014). Peraturan Menteri Pendidikan dan Kebudayaan RI Nomor 59 tahun 2014 tentang Kurikulum SMA/MA. In Lampiran 1 Kerangka Dasar dan Struktur Kurikulum.

Krathwohl, D. R. (2002). A Revision of Bloom's Taxonomy: An Overview. THEORY INTO PRACTICE , 212-218.

Krathwohl, D. R., \& Anderson, L. W. (2014). Kerangka Landasan untuk Pembelajaran, Pengajaran, dan Asesmen. Terjemahan oleh Agung Prihantoro. Yogyakarta: Pustaka Pelajar.

Lewy, Zulkardi, \& Aisyah, N. (2009). Pengembangan Soal untuk Mengukur Kemampuan Berpikir Tingkat Tinggi Pokok Bahasan Barisan dan deret Bilangan di Kelas IX Akselerasi SMP Xaverius Maria Palembang. Jurnal Pendidikan Matematika, 1428.

OECD. (2016, December). Result from PISA (Programme for International Student Assessment) 2015.

Tessmer, M. (1998). Planning and Conducting Formative Evaluations. London: Kogan Page.

Zulkardi. (2006). Formative Evaluation: What, Why, When and How. Dipetik Januari 9, 2018, dari OoCities - Geocities Archive/ Geocities Mirror: http://www.oocities.org/zulkardi/books.html 